\title{
E-GOVERNMENT SUCCESS FACTORS: A PERSPECTIVE ON GOVERNMENT UNITS
}

\author{
Ewa Ziemba, University of Economics in Katowice, Poland, ewa.ziemba@ue.katowice.pl \\ Tomasz Papaj, University of Economics in Katowice, Poland, tomasz.papaj@ue.katowice.pl \\ Maria Jadamus-Hacura, University of Economics in Katowice, Poland, maria.jadamus-hacura@ue.katowice.pl
}

\begin{abstract}
E-government is one of the most important topics of our time. A socio-economic development is not possible without an effectively and efficiently operating e-government. Unfortunately, factors determining the success of e-government are not sufficiently established, especially in developing, emerging and transition countries. Therefore, the aims of this study are to propose a comprehensive success factors framework for e-government and examine differences between identified factors in the context of type, size and region of government units. To reach the aims, the research methods included a critical review of literature, the Delphi study, brainstorming, practical collaboration, logical deduction, survey questionnaire and statistical analysis. The paper continues as follows. First, it discusses the success of e-government and reviews the literature on factors influencing the success. Second, a methodology of examining the success factors for e-government is presented. Third, the framework of success factors for e-government in Poland is provided and the differences between identified factors depending on various kinds of government units are examined. The paper concludes with implications and limitations of this study, and avenues for further research. The study results show that economic, socio-cultural, technological and organizational factors have significant influence on the successful e-government. Furthermore, these factors reflect the access to e-government, e-government competences and the usage of e-government. The study contributes to the existing research by providing the success factors for e-government, especially in the context of the Central and Eastern European countries.
\end{abstract}

Keywords: E-Government, Successful E-Government, Success Factors, Government Units, Poland

\section{INTRODUCTION}

We live in an information society. In this society, a socio-economic development triggered by information and information and communication technologies (ICTs), is not possible without an effectively operating government, and especially an electronic government (e-government). The adoption of e-government requires the ICT adoption for rebuilding government processes and delivering government services electronically to government stakeholders, i.e. citizens, enterprises and government employees. The building of e-government has become a priority issue for many countries, regions and cities, as it has become for Poland and its many regions.

E-government is embedded in combinations of various conditions, especially political, cultural, technological and organizational changes designed to support and drive a profound transformation in government units [18, 21, 22]. Egovernment can be viewed as a highly complex socio-technical system composed of people, technologies, as well as social and organizational structures and processes [27]. The adoption of such a system is not straightforward. It involves a multidimensional approach, the rethinking and reengineering of government processes, changing organizational culture, setting new government law. It requires the coordination of many activities of government units, and a close cooperation among government employees, managers and ICT specialists, as well as citizens and enterprises. In order to adopt e-government, the identification of determinants and barriers influencing the egovernment success is needed. Therefore, enumeration of success factors that are crucial for adopting e-government is becoming an important issue.

The existing studies mostly examine factors affecting the success of e-government in developed countries $[4,7,21$, $22,25]$. However, there is a vacuum of research on this issue in developing countries, especially in the countries of Central and Eastern Europe. The adoption of e-government in transition European countries is generally not considered as successful as in their counterparts in developed countries. The transition countries face serious 
challenges in making ICT work over time and institutionalizing them within the government units $[9,11,20,25]$. After extensively searching the literature, we could only find a few studies concerning success factors for egovernment in the countries of Central and Eastern Europe. This portrays the need for studying which factors affect the success of e-government. This research holds the promise that conducting research among Polish government units should contribute to greater understanding of factors affecting the success of e-government in the countries of Central and Eastern Europe and should help fill the gap in the existing body of knowledge.

The focus of this research, therefore, is on the factors influencing successful e-government in Poland. Its aims are to propose the success factors framework for e-government and examine differences between identified factors depending on the type, size and location (region) of government units. This paper is structured as follows. First, it discusses the success of e-government and reviews the literature on success factors for e-government. Second, the methodology of examining success factors for e-government is presented. Third, the comprehensive framework of success factors for e-government in Poland is delineated and the differences between the identified factors depending on various kinds of government units are identified. The paper concludes with the discussion on the research findings, implications and limitations of this research, and avenues for further studies.

\section{THEORETICAL BACKGROUND}

The e-government success is highly context-dependent. It can be formulated on the basis of various criteria, e.g., time, cost, quality [5], satisfaction of e-government stakeholders [24], and fulfillment of functional requirements [14] Generally, the e-government success means the successful ICT implementation in government units in order to rebuild government processes and provide e-government services for all government stakeholders. Moreover, it means the effective and efficient usage of e-government by all government stakeholders.

The e-government success in achieving is not straightforward. It involves a multidimensional approach, rethinking and reengineering government processes, changing organizational culture, setting new government law. It requires the coordination of many activities of government units, and a close cooperation among government employees, managers and IT specialists, as well as citizens and businesses. Therefore, among other things, enumeration of success factors that are crucial for success in e-government is becoming an important issue.

Several researchers are involved in the discourse on e-government success factors (e.g. Aladwani, 2011; Al-Busaidy and Weerakkody, 2011; Almarabeh, \& AbuAli, 2010; Chu et al., 2004; Gil-Garcia, \& Helbig, 2007; Hwang et al., 2004; Iskender, \& Ozkan, 2013; Mirchandani et al., 2008; Saha et al., 2010; Zhang, \& Hsieh, 2010). Rana et.al [22] analyzed 78 research papers on e-government adoption and identified success factors explored in these studies. The factors mainly concerned developed countries and some Asian countries. It was found that citizen's satisfaction, information accuracy, information exchange, security, privacy and trust, support from the government, ICT skills, facilities offered and efficiency were some of the factors for the success of e-government. Furthermore, Nograšek [19] determined change management as a measure of the e-government success and also assessed its relationship with technology, processes, people, organization culture and structure.

Unfortunately, studies on success factors for e-government are rarely conducted in the countries of Central and Eastern Europe. For example, Ifinedo and Singh [11] addressed the determinants of e-government in the Central and Eastern European countries. They showed that higher levels of human capital resources, greater human capabilities and knowledge, rule of law, availability of ICT infrastructure and more ICT amenities have positive effects on egovernment. Kopackova et al. [16] analyzed the accessibility of local e-government websites and the success of the e-government websites in the Czech Republic. The participants of International Congress in Bratislava [13] indicated seven main obstacles in the successful accomplishment of ICT projects in Slovakia which included public procurement, constant changes in project teams or insufficient legislative. Additionally, Kitsing [15] provided seven factors for explaining e-government success in Estonia: the EU membership, strategic thinking within government to implement e-government, good attention to detail and positive attitude towards ICT policy, innovative thinking, the development of a legal framework, economic growth and macroeconomic stability of the country.

In sum, while there are several studies on the factors for successful e-government in developed and Asian countries, there are only few scattered ones in the countries of Central and Eastern Europe. Therefore, we developed a framework in a systematic and scientific fashion, which incorporates factors contributing to the success of 
e-government in Poland. This framework and identified factors can be a good guideline for the countries of Central and Eastern Europe.

\section{RESEARCH METHODOLOGY}

\section{Research Questions and Hypotheses}

Our research centered upon the following research questions:

Q1: Which factors do influence the success of e-government?

Q2: Do significant differences exist amongst success factors for e-government depending on the types of government units (local and state)?

Q3: Do significant differences exist amongst success factors for e-government depending on the size of government units (number of employees)?

Q4: Do significant differences exist amongst success factors for e-government depending on the region of Poland?

The research hypotheses to be tested were as follows:

H1: Success factors for e-government in state and local government units are significantly different.

H2: Success factors for e-government in government units of different sizes (based on the number of employees) are significantly different.

H3: Success factors for e-government in government units in various regions are significantly different.

\section{Research Procedure}

Research methods included a critical review of the literature, the Delphi technique, brainstorming, collaboration, and statistical analysis. The following steps were taken:

1. The first step. A review of the literature was conducted to identify described success factors for the egovernment adoption. It began with five bibliographic databases: Ebsco, ProQuest, Emerald Management Plus, ISI Web of Knowledge, and Scopus. The search was conducted using a relevant set of keywords and phrases such as "critical success factors," "success factor," "e-government," "electronic government," "success factors," "success," in all possible permutations and combinations. In addition, some dedicated journals in e-government, such as Government Information Quarterly (GIQ), Transforming Government: People, Process, and Policy (TGPPP), Electronic Government: an International Journal (EGIJ), Journal of Global Information Technology Management (JGITM), The Electronic Journal of e-Government (EJEG) were also reviewed. Even open access papers and empirical studies were examined.

2. The second step. The success factors for e-government adoption in the Silesian region in Poland were developed on the basis of practical collaboration among the authors in conjunction with the Silesian Centre of Information Society that is responsible for e-government in the Silesian region.

3. The third step. After careful evaluation of the literature findings, practical collaboration and brainstorming, the success factors for e-government were further refined and a framework of success factors was proposed.

4. The fourth step. Using the Delphi method, the framework of success factors was evaluated and further developed. Twenty two experts participated in the Delphi study. Experts were selected to represent the knowledge and experience of scholars, researchers and practitioners. They included: (a) 16 managers in the local and state government, responsible for e-government adoption in Poland; and (b) 6 professors of Polish universities, who conduct studies and empirical research on e-government. The Delphi process was conducted as a series of rounds. In the early rounds, four experts participated, in the last round all 22 experts participated. In each round, each expert filled out a questionnaire which was delivered to a researcher who 
organized the results and gave back to every expert a summary account of the whole group and the expert's own opinions. In the last round, the experts evaluated the strength of the influence of particular factors on egovernment adoption. The experts had to answer the question: On a scale of $1-5$ rate to what extent do you agree that the following factors influence e-government adoption? A five-point Likert scale was used, as follows: 1 - disagree strongly, 2 - disagree, 3 - neither agree nor disagree, 4 - agree, and 5 - agree strongly. The result of research at this stage is presented in Ziemba et al. [30].

5. The fifth step. The data was analyzed statistically in order to verify and evaluate the success factor framework. The following techniques for data analysis were employed: min, max, mean, median, standard deviation, and coefficient of variation. To conduct reliability analysis, Cronbach's coefficient alpha was used. The conducted statistical analyses could be performed on the small sample size. The statistical and qualitative analyses allowed us to correct the framework of success factors, also in confusing or incomprehensible statements. The result of research at this stage is presented in Ziemba et al. [28].

6. The sixth step. The survey questionnaire was worked out and a five-point Likert scale, described in step 4, was used. Applying the CAWI (Computer-Assisted Web Interview) method and employing the Survey Monkey platform, the survey questionnaire was uploaded to the website.

7. The seventh step. The sample group was defined. It consisted of internal stakeholders of e-government that is government employees working in the government units at the state and local level of government. The research sample was composed of 2,711 government units, comprising 2,268 local government units and 443 state government units, which respectively referred to $81 \%$ of the whole local government and $82 \%$ of purposive sampling of government units at the state level.

8. The eighth step. The data was collected between 22 December 2013 and 15 April 2014. A set of 636 correct and complete responses was collected (response rate $-23.45 \%$ ). The data was stored in two data formats: Statistical Package for Social Science (SPSS) and Microsoft Excel software.

9. The ninth step. Firstly, the reliability was calculated to examine the internal consistency among items on the scale. The Cronbach's alpha values for all the items, research dimensions and stages have values no lower than 0.800 . It shows a strong internal consistency and reliability. Secondly, based on the statistics such as the min, max, mean, median, standard deviation (Std. Dev.) and coefficient of variation (CV), the success factors for e-government in Poland were identified. Kolmogorov-Smirnov test was used to evaluate the normality assumption. The means of success factors in each subgroup of government units were normally distributed, so t-test and analysis of variance (ANOVA) were used to compare the group means. The statistical analysis was made using SPSS and Statistica software.

The research methodology is described in detail in Ziemba et al. [28].

\section{Respondent Demographics}

During the research 636 responses were gathered from respondents who expressed their thoughts about the success factors for e-government. Only one respondent from the same government unit expressed their opinion about the e-government adoption. Descriptive analysis was undertaken to examine the characteristics of the sample. The summarised features of the respondent profile are described in Table 1. The respondents were diverse as regards their characteristics, i.e. type, size and region of government units.

As indicated, 542 (85.22\%) of government units were from the local government, and 94 (14.78\%) of government units were from the state government. With regard to the number of employees of government units, the highest number of government units employed to 50 employees $-279(53.55 \%)$, while the number of government units with the number of employees between 201 and 500 was the lowest $-26(4.99 \%)$.

Table 1. Details About the Research Sample

\begin{tabular}{|l|r|r|}
\hline \multicolumn{1}{|c|}{ Characteristics } & Frequency & Percentage \\
\hline Type of government units & 94 & $14.78 \%$ \\
\hline State & 542 & $85.22 \%$ \\
\hline Local
\end{tabular}


Table 1. Details About the Research Sample

\begin{tabular}{|c|c|c|}
\hline Characteristics & Frequency & Percentage \\
\hline \multicolumn{3}{|l|}{ Size of government units } \\
\hline 50 or fever employees & 279 & $53.55 \%$ \\
\hline 51 to 100 employees & 115 & $22.07 \%$ \\
\hline 101 to 200 employees & 73 & $14.01 \%$ \\
\hline 201 to 500 employees & 26 & $4.99 \%$ \\
\hline 501 or more employees & 28 & $5.37 \%$ \\
\hline \multicolumn{3}{|l|}{ Region of government units } \\
\hline Lower Silesia (R1) & 32 & $5.03 \%$ \\
\hline Kuyavia-Pomerania (R2) & 27 & $4.25 \%$ \\
\hline Lublin (R3) & 43 & $6.76 \%$ \\
\hline Lubusz (R4) & 27 & $4.25 \%$ \\
\hline Łódź (R5) & 29 & $4.56 \%$ \\
\hline Lesser Poland (R6) & 51 & $8.02 \%$ \\
\hline Mazovia (R7) & 84 & $13.21 \%$ \\
\hline Opole (R8) & 19 & $2.99 \%$ \\
\hline Subcarpathia (R9) & 27 & $4.25 \%$ \\
\hline Podlaskie (R10) & 31 & $4.87 \%$ \\
\hline Pomerania (R11) & 29 & $4.56 \%$ \\
\hline Silesia (R12) & 97 & $15.25 \%$ \\
\hline Świętokrzyskie (R13) & 37 & $5.82 \%$ \\
\hline Warmia-Masuria (R14) & 43 & $6.76 \%$ \\
\hline Greater Poland (R15) & 28 & $4.40 \%$ \\
\hline West Pomerania (R16) & 32 & $5.03 \%$ \\
\hline
\end{tabular}

\section{RESEARCH RESULTS}

\section{Framework of E-government Success Factors}

The final framework of success factors for e-government includes 55 factors in various categories. They are economic (E), socio-cultural (S), technological (T) and organizational (O) factors. Moreover, the factors are classified into three groups: e-government access (a) - reflecting e-government technical and economic accessibilities, e-government competences (c) - reflecting competences and awareness related to the adoption of egovernment, and e-government use $(\mathrm{u})$ - reflecting actual usage of e-government by stakeholders. The factors and their descriptive statistics are shown in Table 2.

The calculated means for 55 success factors are in the range from 3.32 to 4.53 , using a five-point Likert scale. Thirty factors have values exceeding 4.0. For eight factors the medians exceed the highest value, namely 5.0, and the means for those factors are higher than the means for the other factors (those factors are highlighted in bold). 
Table 2. Framework of Success Factors for E-Government

\begin{tabular}{|c|c|c|c|c|c|c|c|c|c|}
\hline No. & Critical Success Factor & 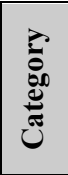 & 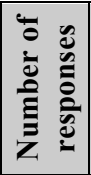 & $\dot{B}$ & $\sum^{\frac{1}{\Sigma}}$ & 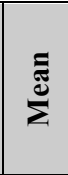 & 总 & $\begin{array}{l}\text { Std. } \\
\text { Dev. }\end{array}$ & $\mathbf{C V}$ \\
\hline $\mathbf{X 1}$ & Public subsidies on hardware, networks and telecommunications & $\mathbf{E} / \mathbf{a}$ & 635 & 1 & 5 & 4.5 & 5 & 0.70 & $15.46 \%$ \\
\hline $\mathrm{X} 2$ & Private outlay on hardware, networks and telecommunications & E/a & 631 & 1 & 5 & 3.4 & 3 & 1.08 & $31.94 \%$ \\
\hline $\mathrm{X} 3$ & Competition on ICT market & E/a & 629 & 1 & 5 & 3.8 & 4 & 0.96 & $24.96 \%$ \\
\hline $\mathrm{X} 4$ & $\begin{array}{l}\text { Public outlay on back-office and front-office information systems, } \\
\text { especially e-government services }\end{array}$ & $\mathrm{E} / \mathrm{a}$ & 633 & 1 & 5 & 4.2 & 4 & 0.84 & $20.12 \%$ \\
\hline X5 & Financial situation of government units & $\mathbf{E} / \mathbf{a}$ & 634 & 2 & 5 & 4.5 & 5 & 0.72 & $15.88 \%$ \\
\hline X6 & Public and private outlay on ICT education for government managers & $\mathrm{E} / \mathrm{c}$ & 634 & 1 & 5 & 4.0 & 4 & 0.81 & $20.06 \%$ \\
\hline $\mathrm{X} 7$ & Public and private outlay on ICT education for government employees & $\mathrm{E} / \mathrm{c}$ & 634 & 1 & 5 & 4.0 & 4 & 0.82 & $20.69 \%$ \\
\hline $\mathrm{X} 8$ & Outlay on creating ICT competence center government units & $\mathrm{E} / \mathrm{c}$ & 632 & 1 & 5 & 3.7 & 4 & 0.87 & $23.63 \%$ \\
\hline X9 & Economic benefits coming from ICT usage in government units & $\mathrm{E} / \mathrm{u}$ & 633 & 2 & 5 & 3.8 & 4 & 0.83 & $21.67 \%$ \\
\hline $\mathrm{X} 10$ & Economic risk of ICT implementation in government units & $\mathrm{E} / \mathrm{u}$ & 631 & 1 & 5 & 3.3 & 3 & 0.87 & $26.27 \%$ \\
\hline $\mathrm{X} 11$ & Public outlay on ICT promotion in government units & $\mathrm{E} / \mathrm{u}$ & 630 & 1 & 5 & 3.7 & 4 & 0.91 & $24.61 \%$ \\
\hline $\mathrm{X} 12$ & $\begin{array}{l}\text { Differentiation of e-government services charges due to ways of } \\
\text { processing - electronic or paper }\end{array}$ & $\mathrm{E} / \mathrm{u}$ & 632 & 1 & 5 & 3.8 & 4 & 1.01 & $26.74 \%$ \\
\hline $\mathrm{X} 13$ & ICT awareness of managerial workers in government units & $\mathrm{S} / \mathrm{a}$ & 634 & 1 & 5 & 4.3 & 4 & 0.87 & $20.41 \%$ \\
\hline $\mathrm{X} 14$ & Citizens' and enterprises' awareness of e-government services & S/a & 635 & 1 & 5 & 4.2 & 4 & 0.84 & $20.04 \%$ \\
\hline $\mathrm{X} 15$ & Public e-services absorption by stakeholders of government units & $\mathrm{S} / \mathrm{a}$ & 635 & 2 & 5 & 4.0 & 4 & 0.80 & $19.92 \%$ \\
\hline X16 & $\begin{array}{l}\text { Incentive system promoting permanent competence improvement of } \\
\text { government employees (especially in ICTs) }\end{array}$ & $\mathrm{S} / \mathrm{c}$ & 636 & 1 & 5 & 4.0 & 4 & 0.86 & $21.32 \%$ \\
\hline $\mathrm{X} 17$ & ICT external expert consultancy for government units & $\mathrm{S} / \mathrm{c}$ & 633 & 1 & 5 & 3.7 & 4 & 0.91 & $24.44 \%$ \\
\hline $\mathrm{X} 18$ & New social and cultural competences of government employees & $\mathrm{S} / \mathrm{c}$ & 633 & 2 & 5 & 3.9 & 4 & 0.82 & $20.86 \%$ \\
\hline X19 & Citizens' and enterprises' competences to use e-government services & $\mathrm{S} / \mathrm{c}$ & 634 & 1 & 5 & 4.1 & 4 & 0.79 & $19.57 \%$ \\
\hline $\mathrm{X} 20$ & Information culture in government units conducive to the use of ICTs & $\mathrm{S} / \mathrm{u}$ & 634 & 2 & 5 & 4.2 & 4 & 0.73 & $17.37 \%$ \\
\hline $\mathrm{X} 21$ & $\begin{array}{l}\text { Social exclusion of workers, citizens, entrepreneurs due to age, to } \\
\text { education, to place of residence, to disability }\end{array}$ & $\mathrm{S} / \mathrm{u}$ & 635 & 1 & 5 & 4.1 & 4 & 0.88 & $21.60 \%$ \\
\hline $\mathrm{X} 22$ & Innovative hardware and networks in government units & $\mathrm{T} / \mathrm{a}$ & 634 & 1 & 5 & 4.1 & 4 & 0.83 & $20.18 \%$ \\
\hline $\mathrm{X} 23$ & Innovative e-government services & $\mathrm{T} / \mathrm{a}$ & 634 & 1 & 5 & 4.1 & 4 & 0.84 & $20.59 \%$ \\
\hline $\mathrm{X} 24$ & Open source software licenses & $\mathrm{T} / \mathrm{a}$ & 634 & 1 & 5 & 4.0 & 4 & 1.00 & $24.71 \%$ \\
\hline $\mathrm{X} 25$ & Standardized ICTs for government units & $\mathrm{T} / \mathrm{a}$ & 630 & 1 & 5 & 4.1 & 4 & 0.87 & $21.55 \%$ \\
\hline X26 & Dedicated (personalized) ICTs for government units & $\mathrm{T} / \mathrm{a}$ & 635 & 1 & 5 & 3.7 & 4 & 1.02 & $27.57 \%$ \\
\hline $\mathrm{X} 27$ & ICT leaderships and visionaries in government units & $\mathrm{T} / \mathrm{c}$ & 635 & 1 & 5 & 3.8 & 4 & 0.93 & $24.32 \%$ \\
\hline $\mathbf{X 2 8}$ & ICT competences of government employees & T/c & 633 & 2 & 5 & 4.4 & 5 & 0.67 & $15.28 \%$ \\
\hline $\mathbf{X 2 9}$ & Integration of front-office and back-office information systems & $\mathbf{T} / \mathbf{u}$ & 633 & 2 & 5 & 4.5 & 5 & 0.68 & $15.24 \%$ \\
\hline $\mathrm{X} 30$ & Interoperability of information systems in government units & $\mathrm{T} / \mathrm{u}$ & 630 & 1 & 5 & 4.2 & 4 & 0.79 & $18.71 \%$ \\
\hline $\mathrm{X} 31$ & Quality of e-government services & $\mathrm{T} / \mathrm{u}$ & 634 & 1 & 5 & 4.3 & 4 & 0.79 & $18.45 \%$ \\
\hline $\mathbf{X 3 2}$ & Information security in government units & $\mathbf{T} / \mathbf{u}$ & 634 & 1 & 5 & 4.3 & 5 & 0.79 & $18.09 \%$ \\
\hline X33 & Maturity of e-government services & $\mathrm{T} / \mathrm{u}$ & 633 & 2 & 5 & 4.2 & 4 & 0.75 & $17.86 \%$ \\
\hline $\mathrm{X} 34$ & E-government services enabling e-voting & $\mathrm{T} / \mathrm{u}$ & 635 & 1 & 5 & 3.6 & 4 & 1.05 & $28.82 \%$ \\
\hline $\mathrm{X} 35$ & $\begin{array}{l}\text { E-government services enabling public consultation and participating in } \\
\text { public decision making }\end{array}$ & $\mathrm{T} / \mathrm{u}$ & 635 & 1 & 5 & 3.7 & 4 & 0.92 & $24.82 \%$ \\
\hline X36 & Coordination of public ICT investments & $\mathrm{O} / \mathrm{a}$ & 636 & 1 & 5 & 4.0 & 4 & 0.87 & $21.94 \%$ \\
\hline $\mathrm{X} 37$ & Coordination of ICT projects in government units & $\mathrm{O} / \mathrm{a}$ & 631 & 1 & 5 & 4.0 & 4 & 0.81 & $20.06 \%$ \\
\hline $\mathrm{X} 38$ & Public-Private Partnership in the field of ICTs & $\mathrm{O} / \mathrm{a}$ & 632 & 1 & 5 & 3.3 & 3 & 0.87 & $26.09 \%$ \\
\hline X39 & Rule of law & $\mathrm{O} / \mathrm{a}$ & 635 & 1 & 5 & 4.1 & 4 & 0.82 & $19.96 \%$ \\
\hline
\end{tabular}


Table 2. Framework of Success Factors for E-Government

\begin{tabular}{|c|c|c|c|c|c|c|c|c|c|}
\hline No. & Critical Success Factor & 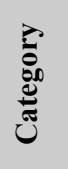 & 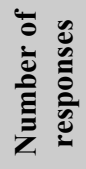 & $\sum$ & $\sum_{\Sigma}^{\check{\Sigma}}$ & 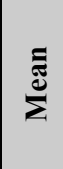 & 胥 & $\begin{array}{l}\text { Std. } \\
\text { Dev. }\end{array}$ & $\mathbf{C V}$ \\
\hline $\mathrm{X} 40$ & Institutional support for the development of ICT infrastructure & $\mathrm{O} / \mathrm{a}$ & 634 & 1 & 5 & 4.1 & 4 & 0.81 & $20.04 \%$ \\
\hline $\mathrm{X} 41$ & Coopetition on ICT market & $\mathrm{O} / \mathrm{a}$ & 633 & 1 & 5 & 3.3 & 3 & 0.86 & $25.65 \%$ \\
\hline $\mathrm{X} 42$ & Corruption in the implementation of ICT projects in government units & $\mathrm{O} / \mathrm{a}$ & 632 & 1 & 5 & 3.3 & 3 & 1.16 & $35.01 \%$ \\
\hline $\mathrm{X} 43$ & ICT benchmarking for local and state government & $\mathrm{O} / \mathrm{a}$ & 633 & 1 & 5 & 3.6 & 4 & 0.83 & $23.24 \%$ \\
\hline $\mathrm{X} 44$ & Approved e-government strategy & $\mathrm{O} / \mathrm{a}$ & 630 & 1 & 5 & 3.6 & 4 & 0.92 & $25.39 \%$ \\
\hline $\mathrm{X} 45$ & State standardization of solutions for e-government & $\mathbf{O} / \mathbf{a}$ & 634 & 1 & 5 & 4.4 & 5 & 0.81 & $18.69 \%$ \\
\hline X46 & $\begin{array}{l}\text { The competence of employees of government units in the field of new } \\
\text { management models }\end{array}$ & $\mathrm{O} / \mathrm{c}$ & 631 & 1 & 5 & 4.1 & 4 & 0.78 & $18.95 \%$ \\
\hline $\mathrm{X} 47$ & Mandatory usage of electronic documents in government units & $\mathrm{O} / \mathrm{u}$ & 634 & 1 & 5 & 4.2 & 4 & 0.82 & $19.60 \%$ \\
\hline $\mathrm{X} 48$ & Top management support & $\mathbf{O} / \mathbf{u}$ & 633 & 1 & 5 & 4.4 & 5 & 0.77 & $17.54 \%$ \\
\hline X49 & $\begin{array}{l}\text { Internal regulations of government units on access to e-government } \\
\text { services }\end{array}$ & $\mathrm{O} / \mathrm{u}$ & 630 & 1 & 5 & 4.0 & 4 & 0.81 & $20.22 \%$ \\
\hline X50 & Adaptation of new management models in government units & $\mathrm{O} / \mathrm{u}$ & 627 & 1 & 5 & 3.9 & 4 & 0.79 & $20.06 \%$ \\
\hline X51 & $\begin{array}{l}\text { Participation of employees of government units in organizational } \\
\text { changes }\end{array}$ & $\mathrm{O} / \mathrm{u}$ & 629 & 1 & 5 & 3.8 & 4 & 0.82 & $21.45 \%$ \\
\hline X52 & Electronic communication between government units & $\mathbf{O} / \mathbf{u}$ & 628 & 1 & 5 & 4.4 & 5 & $\mathbf{0 . 7 0}$ & $16.00 \%$ \\
\hline X53 & New ways of providing work by employees of government units & $\mathrm{O} / \mathrm{u}$ & 629 & 1 & 5 & 3.7 & 4 & 0.91 & $24.40 \%$ \\
\hline X54 & $\begin{array}{l}\text { Access for employees of government units to their network resources } \\
\text { (mobile workstation) }\end{array}$ & $\mathrm{O} / \mathrm{u}$ & 627 & 1 & 5 & 3.6 & 4 & 1.01 & $28.01 \%$ \\
\hline X55 & Citizens' and enterprises' satisfaction with using e-government services & $\mathrm{O} / \mathrm{u}$ & 624 & 1 & 5 & 4.2 & 4 & 0.81 & $19.38 \%$ \\
\hline
\end{tabular}

\section{Differences in Success Factors for E-government Depending on State and Local Government Units}

The first hypothesis tested whether there are significant differences between the success factors for state and local government units. The difference between the means of success factors of two independent samples, i.e. state and local government units was evaluated by independent-samples $t$-test. The test results: $t=0,758, p=0,450$ did not show any significant difference in the means (Figure 1). The result of depth-research on the success factors for the state and local e-government is presented in Ziemba et al. [29].

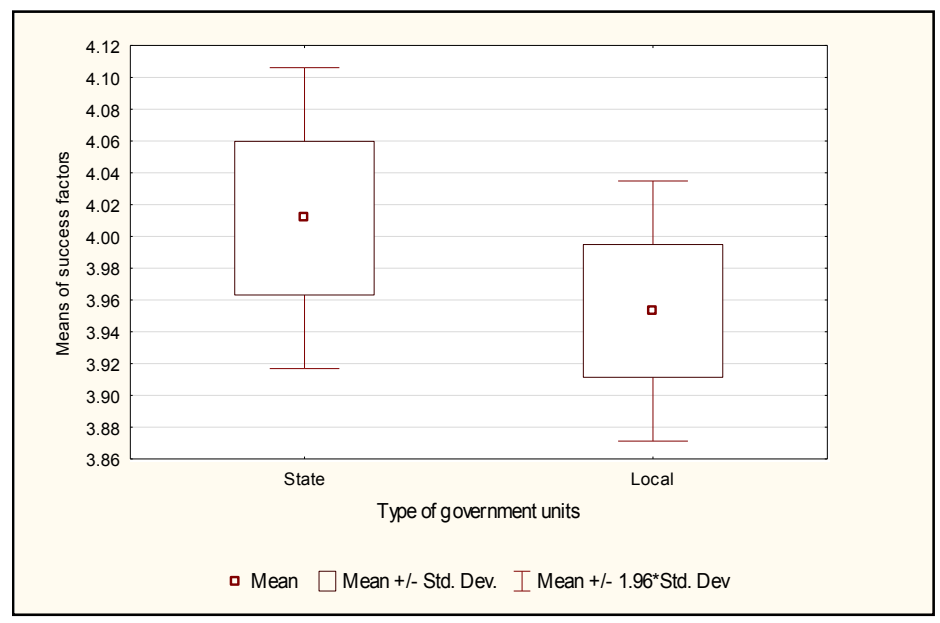

Figure 1. Confidence Intervals for the Means of Success Factors for State and Local Government Units 


\section{Differences in Success Factors for E-government Depending on Size of Government Units}

The second hypothesis tested whether there are significant differences between the success factors for e-government depending on the size of government units. To verify this hypothesis we applied the one-way analysis of variance (ANOVA). The test for homogeneity of the variance was not significant (Levene $\mathrm{F}(1.564)=0.334 ; \mathrm{p}=0.184$ ) indicating that this assumption underlying the application of ANOVA was met. The one-way ANOVA revealed a statistically significant main effect $(\mathrm{F}=6.85 ; \mathrm{p}<0.0001)$ indicating that not all five groups of the government units resulted in the same evaluation of success factors (Figure 2).

Post-hoc comparisons using the Tukey HSD (Honest Significant Difference) test indicated that the means of the government units with more than 100 employees were significantly higher than the means for government units with less than 100 employees. The means and standard deviations of success factors for all groups are shown in Table 3 and Figure 2.

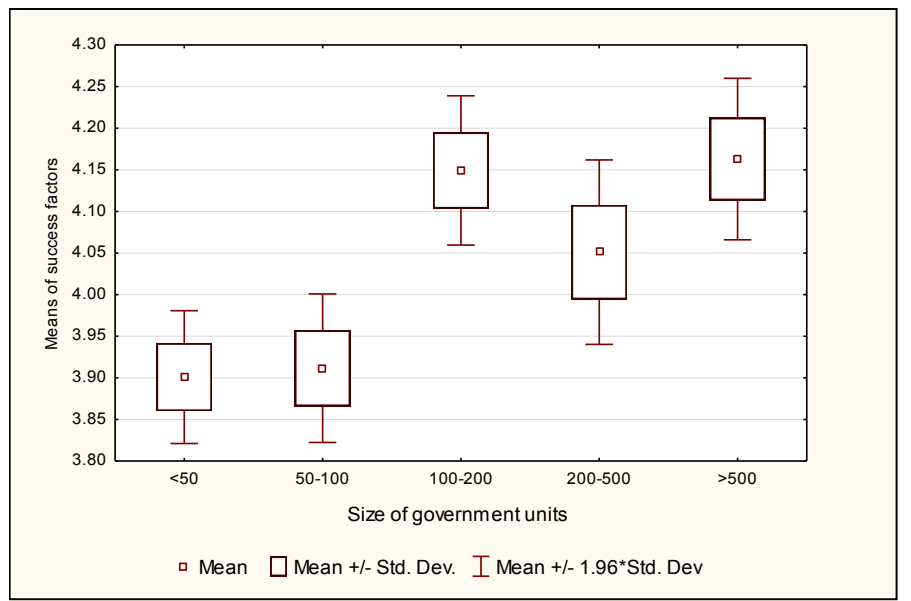

Figure 2. Confidence Intervals for Means of Success Factors for Government Units of Different Size

Table 3. Basic Statistics of Success Factors for Government Units of Different Size

\begin{tabular}{|l|c|c|}
\hline \multicolumn{1}{|c|}{ Size of Government Units } & Mean & Std. Dev. \\
\hline 50 or fever employees & 3.901 & 0.302 \\
\hline 51 to100 employees & 3.912 & 0.338 \\
\hline 101 to 200 employees & 4.149 & 0.339 \\
\hline 201 to 500 employees & 4.051 & 0.420 \\
\hline 501 or more employees & 4.163 & 0.367 \\
\hline
\end{tabular}

There was no statistically significant difference in the mean scores between the first two groups of government units (the number of employees is 100 and fever) and the last three groups (the number of employees is over 100).

\section{Differences in Success Factors for E-government Depending on Region of Government Units}

The third hypothesis tested whether there are significant differences between the success factors for government units in various regions of Poland. The variance in scores was the same for each of 16 regions (Levene $\mathrm{F}(15.864)=0.868 ; \mathrm{p}=0.6$ ), so we could apply the one-way analysis of the variance (ANOVA) to verify the third hypothesis. There was not a statistically significant difference at the mean of success factors level for analyzed groups of the government units (Levene $\mathrm{F}(15.864)=1.35 ; \mathrm{p}=0.167$ ). We can conclude that the evaluation of success factors was not influenced by the administrative division of Poland. 


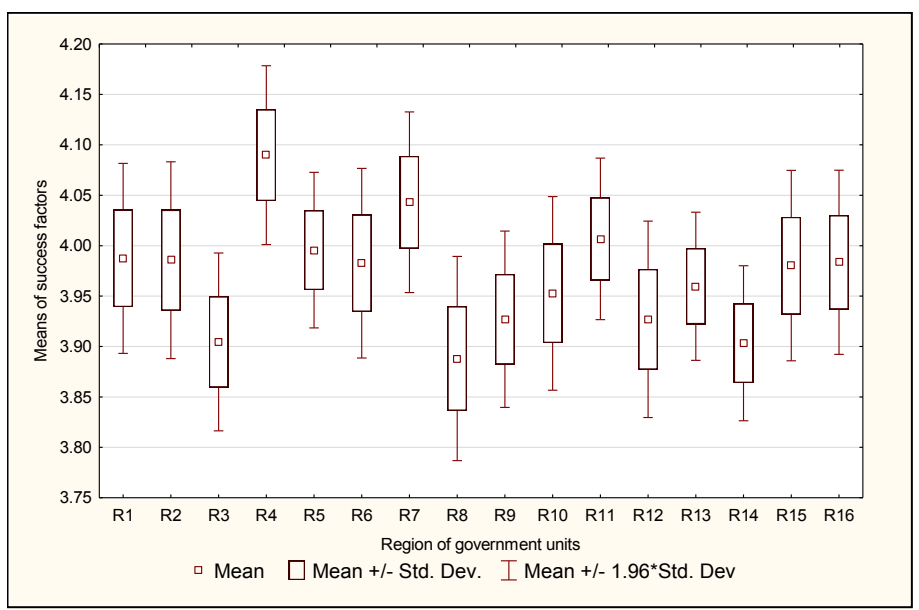

Figure 3. Confidence Intervals for Means of Success Factors for Government Units Operating in Different Regions

\section{Discussion of Findings}

Our results both confirm and extend prior work that investigated the factors affecting the success of e-government. Our study showed that some factors identified in the literature affect the successful e-government. For example, the factors analyzed by Rana, Dwivedi and Williams [22] influence the success of e-government in Poland, i.e. citizen's satisfaction, security, privacy and trust, support from the government, ICT skills, facilities offered and efficiency. Furthermore, we also found that the factors identified for the countries of Central and Eastern Europe, like the EU membership, innovative thinking, strategic ICT thinking within government, rule of law, availability of ICT infrastructure and ICT amenities [11, 13, 15, 16] affect the success of e-government. However, these previous studies did not investigate the role of other factors indicated in the proposed success factor framework (Table 2), e.g. Financial situation of e-government unit, New social and cultural competences of government employees, Citizens' and enterprises' awareness of e-government services, The competence of employees of government units in the field of new management models, Mandatory usage of electronic documents in government units etc. In addition, these previous studies defined some factors at a very general level, e.g. the EU membership. In our study, the factors are more detailed. For example, the EU membership is related to financing e-government projects with European Union funds and functional requirements of e-government. Therefore, the proposed framework includes such factors as Public subsidies on hardware, networks and telecommunications, Public outlay on back-office and front-office information systems, especially e-government services, Public and private outlay on ICT education for government managers, Public outlay on ICT promotion in government units, and Public and private outlay on ICT education for government employees, Interoperability of information systems in government units.

In addition, these previous studies did not examine the differences between the success factors in the context of type, size and the administrative division. We found that (Table 4):

- the success factors for the state e-government are no significantly different from the success factors for the local e-government;

- the success factors for the e-government units with the number of employees 100 and fever are significantly different from the success factors for the e-government units with the number of employees over 100; and

- the success factors for the government units in various regions are no significantly different. 
Table 4. Summary of Hypotheses Testing

\begin{tabular}{|l|c|}
\hline \multicolumn{1}{|c|}{ Hypothesis } & Results \\
\hline H1: Success factors for e-government in state and local government units are significantly different & Not supported \\
\hline H2: Success factors for e-government in government units of different sizes are significantly different & Supported \\
\hline H3: Success factors for e-government in government units in various regions are significantly different & Not supported \\
\hline
\end{tabular}

\section{CONCLUSIONS}

\section{Research Contribution}

This research makes contributions both to theory and practice. The main contribution is to understand the success factors for e-government. The theory contribution of this research is that it analyzes and synthesizes the success factors for e-government in order to enhance knowledge of them from various perspectives. Furthermore, the methodological contribution of this research is that the methodology of success factors examination is developed and described to enhance knowledge and skills of conducting studies on e-government success factors. Moreover, the practical contribution of this research is the employment of this proposed methodology to identify success factors for e-government in Poland and show areas in which satisfactory results will ensure successful e-government.

\section{Implication for Research and Practice}

This study can be useful for researchers. They may use this methodology and do similar analyses with different sample groups in other countries, and many comparisons between different countries can be made. Moreover, the methodology constitutes a very comprehensive basis for identifying success factors for e-government, but researchers may develop, verify and improve this methodology and its implementation.

The research findings can be useful for practitioners. Those identified factors are not unique to the e-government in Poland. They should be definitely useful for developing and emerging countries, especially the transition countries of Central and Eastern Europe. Government practitioners could find answers to important questions about areas and operations of government units that influence e-government. Knowledge about the factors impacting on successful e-government could help governments in developing sound e-government plans and receiving funding from the European Union.

\section{Limitation and Future Research}

As with many other studies, this study has its limitations. Our sample only included Poland's government units. Caution should be taken when generalizing our findings into other countries. Another limitation is that there is only a view point of government units. However, some factors are related to other government stakeholders, i.e. citizens and enterprises. Employing a snapshot research approach in this study is another limitation since we collected the data for the first time. To capture the dynamics of success factors, future longitudinal research may be necessary. In addition, the study does not identify the e-government success factors in the context of small, medium and large government units.

All these above issues should be carefully considered and assimilated in the future works. Now, our studies are related to the identification of the success factors for small, medium and large government unit as well as investigate "demand-side" of e-government from the viewpoint of citizens and enterprises.

\section{ACKNOWLEDGMENTS}

This research has been supported by a grant entitled "Designing a system approach to sustainable development of the information society - on the example of Poland" from the National Science Centre in Poland, 2011/01/B/HS4/00974, 2011-2015. 


\section{REFERENCES}

1. Aladwani, A.M. (2011). Determinants of e-government success in Kuwait. Proceedings of Global Information Technology Management Association World Conference, June 5-7, 2011.

2. Al-Busaidy, M., \& Weerakkody, V. (2011). E-government services in Oman: an employee's perspective. Electronic Government, an International Journal, 8(2/3), 185-207.

3. Almarabeh, T., \& AbuAli, A. (2010). A general framework for e-government: Definition maturity challenges, opportunities, and success. European Journal of Scientific Research, 39(1), 29-42.

4. Anttiroiko, A.V., \& Mälkiä, M. (Eds.) (2007). Encyclopedia of digital government. Hershey: Idea Group Reference.

5. Atkinson, R. (1999). Project management: cost, time and quality, two best guesses and a phenomenon, its time to accept other success criteria. International Journal of Project Management, 17, 337-342.

6. Chu, P.Y., Hsiao, N., Lee, F.W., \& Chen, C.W. (2004). Exploring success factors for Taiwan's government electronic tendering system: behavioral perspectives from end users. Government Information Quarterly, 21, 219-234.

7. Gil-García, J.R. (2012). Enacting electronic government success: An integrative study of government success. An integrative study of government-wide websites, organizational capabilities, and institutions. New York: Springer.

8. Gil-García, J.R., \& Helbig, N. (2007). Exploring e-government benefits and success factors. In A.V. Anttiroiko \& M. Mälkiä (Eds.), Encyclopedia of digital government, 2, 803-811, Hershey: Idea Group Reference.

9. Harindranath, G. (2008). ICT in a transition economy: the case of Hungary. Journal of Global Information Technology Management, 11(4), 33-55.

10. Hwang, M.S., Li, C.T., Shen, J.J., \& Chu, Y.P. (2004). Challenges in e-government and security of information. Information \& Security, an International Journal, 15(1), 9-20.

11. Ifinedo, P., \& Singh, M. (2011). Determinants of eGovernment maturity in the transition economies of Central and Eastern Europe. Electronic Journal of e-Government, 9(2), 166-182.

12. Iskender, G., \& Ozkan, S. (2013). E-government transformation success. An assessment methodology and the preliminary results. Transforming Government: People, Process and Policy, 7(3), 364-392.

13. ITAPA (2013). 12th International Congress of Information Technologies and Public Administration. November 12-13, 2013, Bratislava. Available: http://www.itapa.sk/itapa-congresses/.

14. Joosten, D., Basten, D., \& Mellis, W. (2011). Measurement of information system project success in organizations - What researchers can learn from practice, Proceedings of 19th European Conference on Information Systems ECIS'201, Paper 177.

15. Kitsing, M. (2011). Success without strategy: e-government development in Estonia. Policy \& Internet, 3(1), Article 5.

16. Kopackova, H., Michalek, K., \& Cejna, K. 2007. Accessibility and findability of local e-government websites in the Czech Republic. Universal Access in the Information Society, 9(1), 51-61.

17. Mirchandani, D.A., Johnson, J.H. Jr, \& Joshi, K. (2008). Perspectives of citizens towards e-government in Thailand and Indonesia: a multi-group analysis. Information System Frontier, 10, 483-497.

18. Nfuka, E. N., \& Rusu, L. (2011). The effect of critical success factors on IT governance performance. Industrial Management \& Data Systems, 111(9), 1418-1448.

19. Nograšek, J. (2011). Change management as a critical success factor in e-government implementation. Business System Research, 2(2), 13-24.

20. Nurdin, N., Stockdale, R., \& Scheepers, H. (2012). Organizational Adaptation to Sustain Information Technology: The Case of E-Government in Developing Countries. Electronic Journal of e-Government, 10(1), 70-83.

21. Pina V., Torres, L., \& Royo, S. (2009). E-government evolution in EU local governments: a comparative perspective. Online Information Review, 33(6), 1137-1168.

22. Rana, N.P., Dwivedi, Y.K., \& Williams, M.D. (2013). Analysing challenges, barriers and CSF of egov adoption. Transforming Government: People, Process and Policy, 7(2), 177-198.

23. Saha, P., Nath, A., \& Salehi-Sangari, E. (2010). Success of government e-service delivery: does satisfaction matter? In M.A Wimmer, J.L. Chappelet, M. Janssen \& H.J. Scholl, (Eds), EGOV 2010, Lecture Notes in Computer Science, 6228, 204-215.

24. Xu, X., Zhang W., \& Barkhi, R. (2010). IT infrastructure capabilities and IT project success: a development team perspective. Information Technology and Management, 11(3), 123-142. 


\section{Issues in Information Systems}

Volume 16, Issue II, pp. 16-27, 2015

25. Yun, H.J., \& Opheim, C. (2010). Building on success: The diffusion of e-government in the American States. Electronic Journal of e-Government, 8(1), 71-82.

26. Zhang, Y.J., \& Hsieh, C.T. (2010). Chinese citizens' opinions on e-government benefits, issues and critical success factors. Electronic Government, an International Journal, 7(2), 137-147.

27. Ziemba, E., \& Papaj, T. (2012). E-government application at the regional level in Poland - the case of SEKAP. Proceedings of the Federated Conference on Computer Science and Information Systems, Wroclaw, Poland, 1075-1082.

28. Ziemba, E., Papaj, T. Żelazny, R., \& Jadamus-Hacura, M. (2016). Factors influencing the success of egovernment. Journal of Computer Information Systems (in print).

29. Ziemba, E., Papaj, T., \& Jadamus-Hacura, M. (2015). Critical success factors for adopting state and local egovernment - Polish insights. Proceedings of the 13th International Conference on e-Society 2015, International Association for Development of the Information Society, Madeira, Portugal, 95-102.

30. Ziemba, E., Papaj, T., \& Żelazny, R. (2013). A model of success factors for e-government adoption - the case of Poland. Issues in Information Systems, 14(2), pp. 87-100. 